\title{
Diagnosis of Osteoarticular - Solution is in Peripheral Blood!!
}

\section{Jyoti Prakash*}

Institute of Medical Sciences, Banaras Hindu University, Varanasi, Uttar Pradesh, India

\begin{abstract}
Osteoarticular tuberculosis, a cause of deformity and lifelong disability is usually neglected due to major emphasis on open cases of pulmonary tuberculosis in almost all the developing countries. However, it needs to be detected and treated early. Approximately $10 \%$ of tuberculous infections are extrapulmonary, and $10 \%$ of such infections involve the musculoskeletal system.
\end{abstract}

Keywords: Musculoskeletal; Tuberculosis; Spine; DNA

\section{Introduction}

With the decreased incidence of pulmonary tuberculosis, there is significant decline in the incidence of bone and joint tuberculosis (TB) in developed countries. However, it still remains a serious problem in underdeveloped countries including India [1,2]. In 2012, a total of 8.6 million people fell ill with TB and 1.3 million died of it which included 320,000 HIV infected individuals. In 2012, an estimated 450,000 new cases of multidrug-resistant TB were reported globally [3]. Osteoarticular tuberculosis is an indolent disease, and delay in diagnosis has been reported to be as long as 16 to 19 months [4]. Definite diagnosis of the disease requires demonstration and isolation of the bacterium, for which we need specimens from the affected site. However, it is not feasible to collect affected tissue of osteoarticular tuberculosis due to ethical issues and technical difficulty during the early stage of the disease process. Even if such difficult specimens are collected, acid fast staining mostly fails to detect TB bacilli and the cultures are not positive in $>50 \%$ of the cases due to the paucibacillary nature [5]. In recent years, protocols based on nested polymerase chain reaction (PCR) have raised hopes for a rapid and reliable diagnosis of such osteoarticular tuberculosis because it takes care of PCR inhibitors present in the biological specimens [6,7]. In the recent past, we could detect Mycobacterium tuberculosis (M. tuberculosis) by amplifying specific target using nested PCR in peripheral blood collected from pulmonary tuberculosis cases. Encouraged with this observation, we planned to see the presence of $M$. tuberculosis bacteria in peripheral blood collected from clinically suspected cases of spine, osteoarticular tuberculosis in this study.

\section{Materials and Methods}

The present prospective study was carried out during the period of 2012-2014 in the Department of Microbiology in collaboration with Department of Orthopaedics of the University Hospital of Banaras Hindu University, Varanasi, India. A total of 117 cases were selected based on the clinical and radiological suspicion of tubercular involvement of spine, bone and/or joint presenting with fever, low backache, tibia, knee or elbow swelling not responding to routine antibiotics. The study protocol was approved by the Institutional Ethics Committee (Ethical approval order no - IMS / 08 / 2012 / 113 ) and informed consent was taken from each of the patients.

The samples were collected under strict aseptic precautions in the operation theatre. The specimens were synovial fluid, disc, bone marrow aspirate and pus from the diseased part/ tissues, such as synovial or vertebral bone (closed or open biopsy) and blood. All the samples were subjected to nested PCR after DNA extraction.
DNA was extracted from the specimens following the methods described by Sambrook et al. [8]. We determined absorbance of extracted DNA at $260 / 280 \mathrm{~nm}$ and $5 \mu \mathrm{L}$ was taken for gene amplification by PCR, coding for the $32-\mathrm{kDa}$ protein. Heat shock protein gene (hsp65) of M. tuberculosis, a conserved gene was targeted and an in house designed already tested primers hsp TBF1 and hsp TBR1 were used for amplification of a 494 bp nucleotide sequence by primary PCR; hspTBF2 and hspTBR2 for amplification of a nucleotide sequence by nested PCR [9].

The oligo sequences (5'-3') were as follows:

\section{For Primary PCR:}

hspTBF1: AAA AGC CGG ATG GCA ATT CG

hspTBR1: ATT ACC GGC TTG GAC CCC CTG

For Nested PCR:

hspTBF2: ATG CGG CGC ACA CCG AAG ACA AG

\section{hspTBR2: TCA ACG CGC TGT CTA GCT TGT C}

PCR reaction was carried out in $25 \mu$ volume. Reaction mix contained $10 \mathrm{x}$ reaction buffer $(5 \mu \mathrm{l} / \mathrm{sample})$, dNTPs $(2.5 \mathrm{mmol}$ each base), forward and reverse primers (concentration $10 \rho \mathrm{mol} / \mu \mathrm{l}$ ) and Taq polymerase enzyme (1U). Amplification was carried out on Bio Rad, Thermo Cycler, with a heated lid. The hot start method was employed by heating at $94^{\circ} \mathrm{C}$ for $5 \mathrm{~min}$ initially. Thereafter, amplification was carried out for $35 \mathrm{cycles}$ at $92^{\circ} \mathrm{Cfor} 1 \mathrm{~min}$ (denaturation), $65^{\circ} \mathrm{C}$ for $1 \mathrm{~min}$ (annealing) and $72^{\circ} \mathrm{C}$ for $1 \mathrm{~min}$ (extension). Extra extension was carried out at $72^{\circ} \mathrm{C}$ for $7 \mathrm{~min}$. The amplification products of primary PCR was again amplified with nested primers following same protocol. The final amplification products were analyzed on $2 \%$ agarose gel stained with ethidium bromide under UV light. Positive (DNA extracted from $M$. tuberculosis growth) and negative (double distilled water) controls were run with each batch of samples analysed. In our study, we used

*Corresponding author: Jyoti Prakash, Institute of Medical Sciences, Banaras Hindu University, Varanasi, Uttar Pradesh, India, Tel: 917839166976; E-mail: prakash_jyoti31@yahoo.com

Received January 30, 2016; Accepted February 17, 2016; Published February 27, 2016

Citation: Prakash J (2016) Diagnosis of Osteoarticular - Solution is in Periphera Blood!! J Microb Biochem Technol 8: 107-109. doi: 10.4172/1948-5948.1000271

Copyright: @ 2016 Prakash J. This is an open-access article distributed under the terms of the Creative Commons Attribution License, which permits unrestricted use, distribution, and reproduction in any medium, provided the original author and source are credited. 
the reference strain $\mathrm{H} 37 \mathrm{Rv}$ M. tuberculosis as positive control and a reagent blank (no target DNA) as negative control.

\section{Observation}

In our study mean age of the patients was $47.5 y e a r s$ (range 36 to 64 years) (Table 1). Depending upon pain, inflammatory pattern and limitation of movement clinical diagnosis of osteoarticular tuberculosis was made (Figures 1 and 2) We had collected synovial fluid from 21 patients of suspected knee joint tuberculosis, 37 sample of pus, 58 sample of disc material and 1 sample of bone marrow aspiration. Conventional staining for acid fast bacteria by Ziehl Neelsen staining came out to all negative results. While on heat shock protein (hsp) gene amplification by PCR technique revealed enthusiastic result. 09 out of 27 synovial fluid sample came out with positive band for $M$. tuberculosis. 16 out of 37 pus sample and 21 out of 58 sample of disc material also had positive band. We also had 01 sample of bone marrow aspiration which was also found positive on Nested PCR. All together out of the 117 specimens examined, 47 (40\%) were found PCR positive for M. tuberculosis. Nested PCR done in the blood samples from these 47 cases showed a positivity of $(14 / 47,30 \%)$ (Table 2$)$.

\begin{tabular}{|c|c|}
\hline Variable & Patients \\
\hline Age & 47.5 Yrs ( Range $36-64$ yrs) \\
\hline Sex & Male $-32(68 \%)$ \\
& Female $-15(31 \%)$ \\
\hline Affected site & Spine- $30(63 \%)$ \\
& Knee- $9(19 \%)$ \\
Hip- $5(10 \%)$ \\
\hline
\end{tabular}

Table 1: Demographic data of patients of Osteoarticular Tuberculosis.

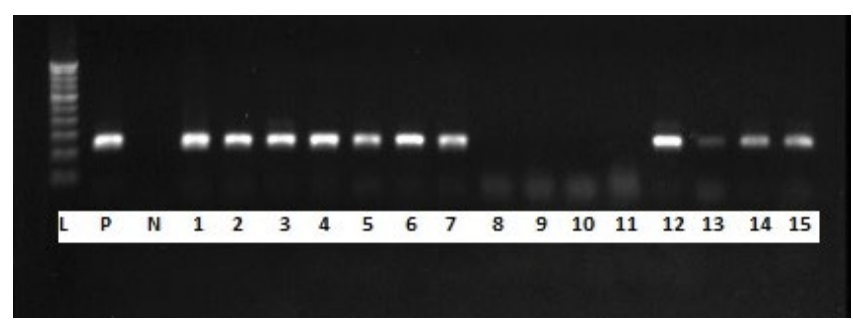

L: Ladder; P: Positive control (218 bp); N: Negative control,

Samples: 1, 2, 3, 4, 5, 6, 7, 12, 14, 15 Positive; Lane: 8, 9, 10, 11, 13 are Negative

Figure 1: Amplification of heat shock protein gene specific sequences of Mycobacterium tuberculosis in specimens of affected tissues.

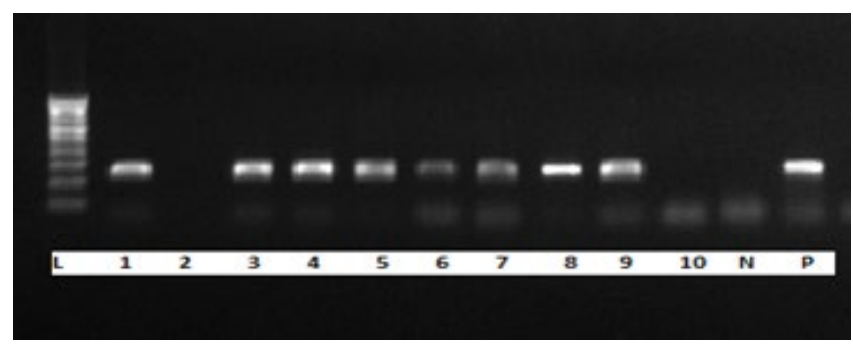

L: Ladder; P: Positive control (218 bp); N: Negative control,

Lanes 1, 3,5,7,9 are the specimens and lanes 2, 4, 6,8,10 are their corresponding blood samples.

Figure 2: Amplification of heat shock protein gene specific sequences of Mycobacterium tuberculosis in positive specimens and corresponding blood of patients for the bacterium.

\section{Discussion}

This study was done with 117 patients with mean age of 47.5 years which was in same trend as reported by Guadalupe et al. [9]. Maximum affected site in our study was spine which also coincide with other study with an edge of comparative more number of extra spinal involvement [9-11]. A well-known problem in specimen collection from clinically suspected cases of osteoarticular tuberculosis and inadvertent delay in the start of antitubercular therapy due to diagnostic dilemma, the present; although small study indicates that mycobacterial DNA do circulate in peripheral blood in cases of pauci bacillary tuberculosis also. There are a few studies that have shown not only the presence of the bacterium but more positivity in peripheral blood than affected tissue in pauci bacillary tuberculosis. Miyazaki et al. by using nested PCR was able to show the presence of M. tuberculosis DNA in $16.6 \%$ (4/24) of the military tuberculosis cases [10]. A study from Brazil carried out on blood collected from clinically suspected cases of tuberculosis of paediatric age group showed significantly higher detection of $M$. tuberculosis by nested PCR in extra pulmonary than that obtained in the cases of pulmonary TB. However, in this study the authors have not examined the specimens from affected part of the body [11]. Another study from Taiwan, targeting mpt64 gene has shown that the circulation of bacilli in the peripheral blood is more likely in cases of the extra pulmonary form of the disease than the pulmonary [12]. Another group of authors have indicated the difficulty in finding $M$. tuberculosis in extra pulmonary specimens, in which there are few bacilli, leading to low sensitivity of smear microscopy and of culture [13]. The authors have also implicated the presence of inhibiting factors that can interfere in the DNA amplification using PCR. However, in our study using the blood of pauci bacillary patients, we found the sensitivity of PCR to be quite good in extra pulmonary cases. Although, no explanation has been given by the previous workers why the TB PCR positivity was low in pulmonary cases, it seems to be an advantage to the pauci bacillary cases. These DNA can be detected by using sensitive and specific nested PCR. Positivity of the $M$. tuberculosis nucleic acid marker in $1 / 3^{\text {rd }}$ of those cases whose affected tissues were also positive for hsp specific amplification of the bacterium, indicates the possibility of better sensitivity if we would have examined multiple blood specimens collected at different sittings or large volume of blood is collected or nested PCR is carried out in DNA isolated from Buffy coat probably carrying the bacterium. Further, if mRNA is isolated from the peripheral blood and either nested or real time PCR is performed, the sensitivity of detection may improve as copy number of mRNA will naturally is much more than the chromosomal DNA of the bacterium. Detection of mRNA further will confirm the viability of bacteria. Further advantages of PCR include: (1) Efficient and rapid method for diagnosis ( $48 \mathrm{~h}$ ). (2) A PCR result is of great value in early diagnosis, particularly in infections of certain body systems where disease progression is rapid and detection by culture method is time-consuming. (3) Detect minute of bacterium hence treatment can be started early if there are associated clinical signs of the disease. (4) Differentiation between typical and atypical mycobacterium. (5) Detection of alpha crystalline by Real Time PCR help in detection of even latent osteoarticular tuberculosis Nazia Rizvi et al. [14-17] PCR can also detect very low levels AFB in clinical specimens and results are available within two days. However, misleading results can occur, such as the smallest amount of contaminating DNA can be amplified. A PCR-positive result does not always correlate with culture results and PCR is not a substitute for culture; it is an ancillary study complementing the routine battery of laboratory tests conducted for the rapid and definitive diagnosis of TB. 
Citation: Prakash J (2016) Diagnosis of Osteoarticular - Solution is in Peripheral Blood!! J Microb Biochem Technol 8: 107-109. doi: 10.4172/19485948.1000271

\begin{tabular}{|l|c|c|c|c|c|c|}
\hline \multicolumn{1}{|c|}{ Specimens } & Synovial Fluid & Pus & $\begin{array}{c}\text { Disc } \\
\text { specimen }\end{array}$ & Bone marrow aspirate & Total positivity in non-blood samples & $\begin{array}{c}\text { Blood from patients positive for } \\
\text { amplification }\end{array}$ \\
\hline PCR positive / Total & $9 / 21$ & $16 / 37$ & $21 / 58$ & $1 / 1$ & $47 / 117$ \\
number of the sample & $(43)$ & $(43.24)$ & $(36.2)$ & $(100)$ & $(40.1)$ \\
\hline
\end{tabular}

Figures in parenthesis are percentages.

Table 2: Showing positivity for specific heat shock protein (hsp) gene of M. tuberculosis in different samples collected from suspected cases of tuberculosis.

Its disadvantages include an inability to differentiate live from dead organisms, since it does not depend on bacterial replication and it provides no information on disease activity. Developing country like India where cost and availability of Nested PCR brings a limitation of its use even though it increases the number of definite diagnoses and provided highly specific and sensitive results within $48 \mathrm{~h}$. Minimally, if possible, AFB smear and histopathology of tissue specimens can be carried out at a much lower cost and can increase the number of definite diagnoses. Nested PCR has great potential in improving the clinicians' ability to rapidly diagnose clinically suspected TB, which will ensure early patient treatment [18]. This is a preliminary study looking into a pauci bacillary tuberculosis infection of bone joints and disease. The encouraging results suggest for a study involving large number of subjects which will definitely provide better clues in peripheral blood samples before the development of serious morbidity and mortality of tuberculosis of spine, bone and joint.

\section{References}

1. Shah AA, Ahmed S, Shah H, Raziq F (1992) Bone tuberculosis in Abbottabad. J Pak Med Assoc 42: 180-181.

2. Shannon FB, Moore M, Houkom JA, Waecker NJ Jr (1990) Multifocal cystic tuberculosis of bone. Report of a case. J Bone Joint Surg Am 72: 1089-1092.

3. Global strategy and targets for tuberculosis prevention, care and control after 2015 World Health Organization 2013.

4. Williams KD (1998) Tuberculosis and other unusual infections. Tuberculosis. 12: $626-627$

5. Hopewell PC (1999) Overview of clinical tuberculosis. Tuberculosis 7: 25-46.

6. Eisenach KD, Cave MD, Crawford JT (1999) PCR detection of Mycobacterium tuberculosis. 191-196. Medicine 5: 489-499.
7. Iseman MD (1996) Tuberculosis, epidemiology in bennet jc. J Trop Biomed 13: $1683-1684$.

8. Sambrook J (2000) Molecular Cloning: A Laboratory Manual, $3^{\text {rd }}$ Edition, Cold Spring Harbor Laboratory Press, New York.

9. Garcia E, Olga G, Cesan B (2014) Clinical, radiological,and molecular diagnosis correlation in serum sample from patients with osteoarticular tuberculosis. Asian pacific J Trop Biomed 4: 581-585.

10. Ansari S, Amanullah MF, Ahmad K, Rauniyar RK (2013) Pott's Spine: Diagnostic Imaging Modalities and Technology Advancements. N Am J Med Sci 5: 404-411.

11. N A, Ahmad F, Huda N (2013) Osteoarticular tuberculosis-a three years' retrospective study. J Clin Diagn Res 7: 2189-2192.

12. Sareen A, Khare GN, Nath G, Singh S (2006) Role of polymerase chain reaction in osteoarticular tuberculosis. Indian J Ortho 40: 264-266.

13. Miyazaki Y, Koga H, Kohno S, Kaku M (1993) Nested polymerase chain reaction for detection of Mycobacterium tuberculosis in clinical samples. J Clin Microbiol 31: 2228-2232.

14. Honore S, Vincensini JP, Hocqueloux L, Noguera ME, Farge D, et al. (2001) Diagnostic value of a nested polymerase chain reaction assay on peripheral blood mononuclear cells from patients with pulmonary and extra-pulmonary tuberculosis. Int J Tuberc Lung Dis. 5: 754-762.

15. Shin Wu, Cheng Ho (2013) Diagnosis of Tuberculosis by PCR-based Amplification of mpt64 Gene from Peripheral Blood. IJBLS 1: 25-30.

16. Honoré-Bouakline S, Vincensini JP, Giacuzzo V, Lagrange PH, Herrmann $\mathrm{JL}$ (2003) Rapid diagnosis of extrapulmonary tuberculosis by PCR: impact of sample preparation and DNA extraction. J Clin Microbiol 41: 2323-2329.

17. Nazia Rizivi, Singh A ,Ali S, Yadav M (2015) Expression of Alpha Crystallin Protein in Osteoarticular Tuberculosis in Latent Phase: A Review of Evidences. International Journal of Biomedical Research 6: 445-451.

18. Kamara E, Mehta S, Brust JC, Jain AK (2012) Effect of delayed diagnosis on severity of Pott's disease. Int Orthop 36: 245-254. 